\title{
USING DEHYDRATED AIR IN DRYING GARLIC SLICES
}

\author{
Taha $^{(1)}$, A. T. and Hadeer S. Farouk ${ }^{(2)}$
}

\section{ABSTRACT}

The aim of this study is to investigate a new drying method that depend on absorbing the moisture from the air using some desiccants which have a great affinity for moisture; so when the wet air passes through the desiccants it becomes less wet and its temperature becomes a little higher ranging from 2 to $4^{\circ} \mathrm{C}$. The used desiccants were sulfuric acid conc., calcium chloride anhydrous and silica gel. The experiments were done in two stages the first stage was without drying load on purpose of choosing the best treatment that provides high dehydrated air. The best treatment for dehydrating the air was when air passes with the lowest velocity 2.0 $\mathrm{m} / \mathrm{s}$ in succession through four desiccants; $500 \mathrm{ml} \mathrm{H}_{2} \mathrm{SO}_{4}, 500 \mathrm{~g} \mathrm{CaCl}$, $500 \mathrm{ml} \mathrm{H}_{2} \mathrm{SO}_{4}$ and $500 \mathrm{~g} \mathrm{SiO} \mathrm{S}_{2}$, with moisture uptake percentage from $56.77 \%$ to $18.2 \%$. In the second stage we used oven dryer at $70{ }^{\circ} \mathrm{C}$ and Desiccant Drying System (DDS) with the best treatment in drying garlic with slices thickness $3 \mathrm{~mm}$. Three levels of loading were used 1.15, 2.3 and $4.6 \mathrm{Kg} / \mathrm{m}^{2}$. The quality of the dried garlic slices were evaluated for color and oil content. The results revealed that using the DDS method provides a good quality dehydrated garlic slices with higher oil content and lower color change. It also involved low energy consumption and high drying efficiency compared to the slices dried by using oven dryer.

Keywords: Desiccant drying system; Desiccants; Dehydrated air; Garlic, and Drying efficiency.

\section{INTRODUCTION}

7 he main purpose in drying farm produce is to reduce its water activity from the harvest level to the safe storage level in order to extend its shelf life. Once the product has been dried, its rate of deterioration due to respiration, insects, and microbial activity and biochemical reactions should diminish leading to maintenance of quality of the stored product. It is improve bargaining position of the farmer to maintain relatively constant price of his product (Papu et al., 2014).

(1) Assistant professor, Agric. Eng. Dept., Faculty of Agric., Menoufia University.

(2) Searcher, Agric. Eng. Dept., Faculty of Agric., Menoufia University. 
Food materials and crops are very sensitive to the drying conditions. Drying must be performed in a way that does not affect seriously their color, flavor, or nutritional value. Thus the selection of drying conditions, as temperature, is of major importance (Belessiotis and Delyannis, 2011). Reducing amount of demanded energy and time consuming for drying process are important issues for drying technology owing to the rise in fuel prices which increases the drying process costs and reduces the profit margins of industries involved in drying (Aktas et al., 2017). There are three ways of reducing the air humidity such as (a) reducing air's temperature to condense moisture, (b) increase the total pressure, also results condensation, (c) bringing the air in contact with desiccant. This third way is quite interesting and cost saving too. Since there are some drawbacks of this system i.e. low moisture removal rate, pressure drop in solid desiccants and liquid desiccant evaporation into atmosphere, but these problems can be reduced to minimal by using better design (Singh et al., 2017). Good desiccant materials share the two important characteristics of high transient dehumidification ability and large sorption capacity. Silica gel, activated carbon, activated alumina, zeolite, and molecular sieve are all commonly used in desiccant dehumidifier systems. Each material has its own advantages with different adsorption characteristics. Zeolite is usually used at low pressures, but generally has low sorption capacity. Moreover, it requires more than $100{ }^{\circ} \mathrm{C}$ to regenerate. Molecular sieves are more expensive than other common adsorbents. Activated carbon has a large internal surface area and porosity, so it has a large sorption capacity. However, carbon is more suitable for use in conditions of relative humidity greater than $70 \%$ due to its poor hydrophobicity (Huang H. et al., 2010). The advantages of using a liquid desiccant system that it is flexible and can position the regeneration area far away from the dehumidification zone. Liquid desiccant can also absorb organic and inorganic contaminants from the air. One drawback of the liquid desiccant is carrying over by air stream during the dehumidification and regeneration process. However, proper dehumidifier and regenerator design will reduce or eliminate this problem (Gandhidasan, 2004). Garlic has been cultivated for centuries all over the world on account of its culinary and medicinal properties. It is mainly 
used as a food additive in various food preparations such as flavoring mayonnaise and tomato ketchup sauce, salad dressing, meat sausages, stews spaghetti, chutney pickles, etc. Therefore garlic is produced abundantly and consumed as such, little efforts have so far been made to produce dehydrated garlic and garlic powder. (Sharma and Prasad, 2001). The final color characteristics values of dried garlic slices such as lightness, yellowness and redness were affected significantly by the air temperature and slice thickness at their studied ranges. Increasing in the both of air temperature and thickness of samples and decreasing in the moisture content of sample caused a darker dried-product. So using the low air temperature and thin slice is necessary to achieve best color and good appearance (Rasouli et al., 2011).

\section{MATERIALS AND METHODS}

\subsection{Desiccant Drying System (DDS)}

DDS was fabricated and installed in the Lab of Agric. And Bio Eng. Department, Faculty of Agric. Menoufia Univ. DDS consists of three main parts as shown in fig. 2.1 which are: desiccant flasks, compressor and drying chamber.

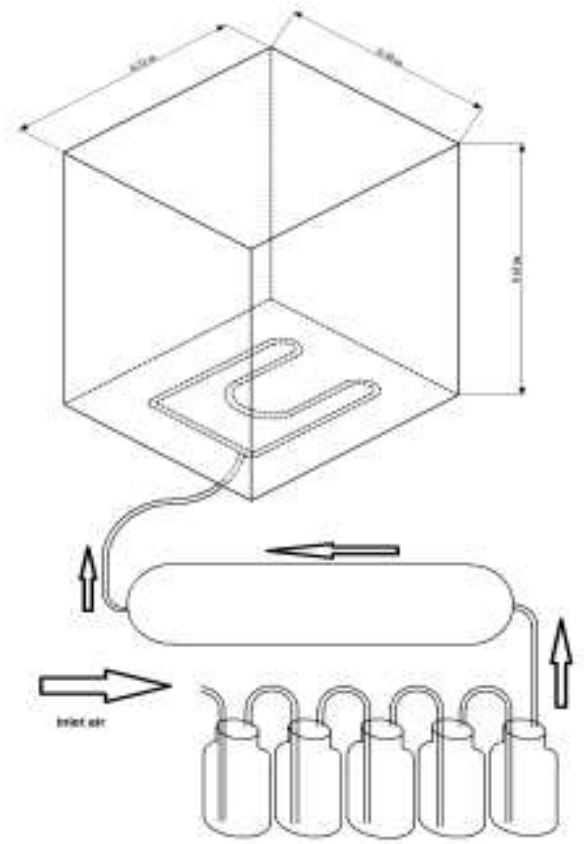

Fig. 2.1. Desiccant Drying System. 


\subsection{Desiccant materials}

Three desiccants were used; Sulfuric acid, Calcium chloride and Silica gel. Their properties are shown in table 2.1

\begin{tabular}{|l|l|l|l|}
\hline & Desiccant (1) & Desiccant (2) & Desiccant (3) \\
\hline Common name & Sulfuric acid & $\begin{array}{l}\text { Calcium } \\
\text { chloride }\end{array}$ & Silica gel \\
\hline $\begin{array}{l}\text { Chemical } \\
\text { formula }\end{array}$ & $\mathrm{H}_{2} \mathrm{SO}_{4}$ & $\begin{array}{l}\mathrm{CaCl}_{2} \\
\text { (anhydrous) }\end{array}$ & $\mathrm{SiO}_{2}$ \\
\hline Molar mass & $98.08 \mathrm{~g} / \mathrm{mol}$ & $110.99 \mathrm{~g} / \mathrm{mol}$ & $60.08 \mathrm{~g} / \mathrm{mol}$ \\
\hline Appearance & Clear & $\begin{array}{l}\text { powder, } \\
\text { hygroscopic }\end{array}$ & $\begin{array}{l}\text { Transparent } \\
\text { beads }\end{array}$ \\
\hline Status & Liquid & Solid & Solid (pellets) \\
\hline Color & Colorless & White & Blue \\
\hline Odor & Odorless & Odorless & Odorless \\
\hline Min Assay & $98.0 \%$ & $99.5 \%$ & $99.0 \%$ \\
\hline \begin{tabular}{l} 
Density \\
\multicolumn{1}{|c|}{ amount }
\end{tabular} & $1.84 \mathrm{~g} / \mathrm{cm}^{3}$ & $2.15 \mathrm{~g} / \mathrm{cm}^{3}$ & $\begin{array}{l}1.11 \\
\mathrm{~g} / \mathrm{cm}^{3}\end{array}$ \\
\hline $\begin{array}{l}\text { Used } \\
\text { per once }\end{array}$ & $500 \mathrm{ml}$ & $500 \mathrm{gm}$ & $500 \mathrm{gm}$ \\
\hline $\begin{array}{l}\text { Regeneration } \\
\text { ability }\end{array}$ & Possible & Possible & Possible \\
\hline
\end{tabular}

\subsection{Absorbing the moisture from air}

For reducing the air relative humidity three levels of air velocity (2- 4.5- 7 $\mathrm{m} / \mathrm{s}$ ) were used in combination with three desiccants singular and in combination with four configurations of them were used. These configurations were, Conf. 1 a succession of two flasks of $\mathrm{H}_{2} \mathrm{SO}_{4}$ and $\mathrm{CaCl}_{2}$. Conf.2 a succession of three flasks of $\mathrm{H}_{2} \mathrm{SO}_{4}, \mathrm{CaCl}_{2}$ and $\mathrm{SiO}_{2}$. Conf.3 a succession of four flasks of $\mathrm{H}_{2} \mathrm{SO}_{4}, \mathrm{CaCl}_{2}, \mathrm{H}_{2} \mathrm{SO}_{4}$ and $\mathrm{SiO}_{2}$. Conf. 4 a succession of five flasks of $\mathrm{H}_{2} \mathrm{SO}_{4}, \mathrm{CaCl}_{2}, \mathrm{H}_{2} \mathrm{SO}_{4}, \mathrm{SiO}_{2}$ and $\mathrm{H}_{2} \mathrm{SO}_{4}$.

\subsection{Garlic properties}

Freshly-harvested garlic cloves (Allium Sativum) were used for the experimental work with three levels of loading; $\left(1.15 \mathrm{~kg} / \mathrm{m}^{2}-2.3 \mathrm{~kg} / \mathrm{m}^{2}-\right.$ $\left.4.6 \mathrm{~kg} / \mathrm{m}^{2}\right)$. Damaged, diseased, and immature bulbs were sorted out and the unharmed fresh garlic bulbs were selected for the study. The moisture content of initial products was determined according to (AOAC, 1995) by 
drying the products in an electrical oven at $70^{\circ} \mathrm{C}$ for 24 hours and was $1.82 \mathrm{~g}$ water/g dry matter.

\subsection{Measurements}

\subsubsection{Air velocity:}

The air velocity inside the drying chamber was measured by Anemometer

\subsubsection{Temperature and relative humidity}

The dry bulb temperature and wet bulb temperature of the air $\left({ }^{\circ} \mathrm{C}\right)$ were measured using a CR23X data logger. The air relative humidity was obtained by using the psychrometric chart.

Then the air moisture uptake percentage for desiccant materials and the configurations of them, represented as:-

$$
\Delta R H=\frac{R H \text { in }- \text { RH out }}{R H i n} \quad \% .
$$

$\mathrm{RH}_{\text {in }}=$ the air relative humidity before dehydrating.

$\mathrm{RH}_{\text {out }}=$ the air relative humidity after dehydrating.

\subsubsection{Weight (Electric balance):}

Initial and final mass and mass changes during drying processes of each sample were measured by electric balance with accuracy of $0.01 \mathrm{~g}$. The digital balance was kept very close to the drying unit and each weight measurement process took about $10 \mathrm{~s}$, according to (Sharma and Prasad 2001).

\subsubsection{Surface colour measurements:}

Surface colour of both fresh and dried garlic slices was measured using a WR-10 Colorimeter to obtain the colour values, which measured using three parameters: lightness $(\mathrm{L})$, redness $(+a)$ and yellowness $(+b)$.

The total colour difference $(\Delta \mathrm{E})$ and browning index $(\mathrm{Bi})$ was then determined using the following equation:

$$
\Delta \boldsymbol{E}=\sqrt{(\Delta \boldsymbol{L})^{2}+(\Delta \boldsymbol{a})^{2}+(\Delta \boldsymbol{b})^{2}}
$$

The fresh garlic slices were used as the reference and a higher $\Delta \mathrm{E}$ represents greater colour change from the reference material (Kamil and Ahmet, 2006).

\subsubsection{Energy consumption:-}

Energy consumption was measured in W.hr by energy meter. 


\subsubsection{The Drying Efficiency $\left(\eta_{0}\right)$ :}

The drying efficiency $\eta_{\mathrm{o}}$ is the ratio of the theoretical energy required to evaporate the moisture from the crop to the used energy.

$$
\eta o=W r * \frac{L H V}{P} * 100
$$

$\mathbf{W}_{\mathbf{r}} \quad$ = water removal per second

LHV = Latent heat of vaporization $\left(2.260 * 10^{6}\right)$

$\mathbf{P} \quad=$ Power consumed

$(\mathrm{J} / \mathrm{Kg})$.

(W).

\section{RESULTS AND DISCUSSION}

\subsection{The average of moisture uptake using three singular desiccants:}

The data illustrated that the increase in the air velocity from 2 to $7 \mathrm{~m} / \mathrm{s}$ decreases the ability of desiccants for moisture uptake by $52.32 \%$, $55.96 \%$ and $57.16 \%$ for the desiccants $\mathrm{SiO}_{2}, \mathrm{H}_{2} \mathrm{SO}_{4}$ and $\mathrm{CaCl}_{2}$ respectively as shown in fig. 3.1. Similar results have been noted by (Rihan and Abd el-bary,2009).

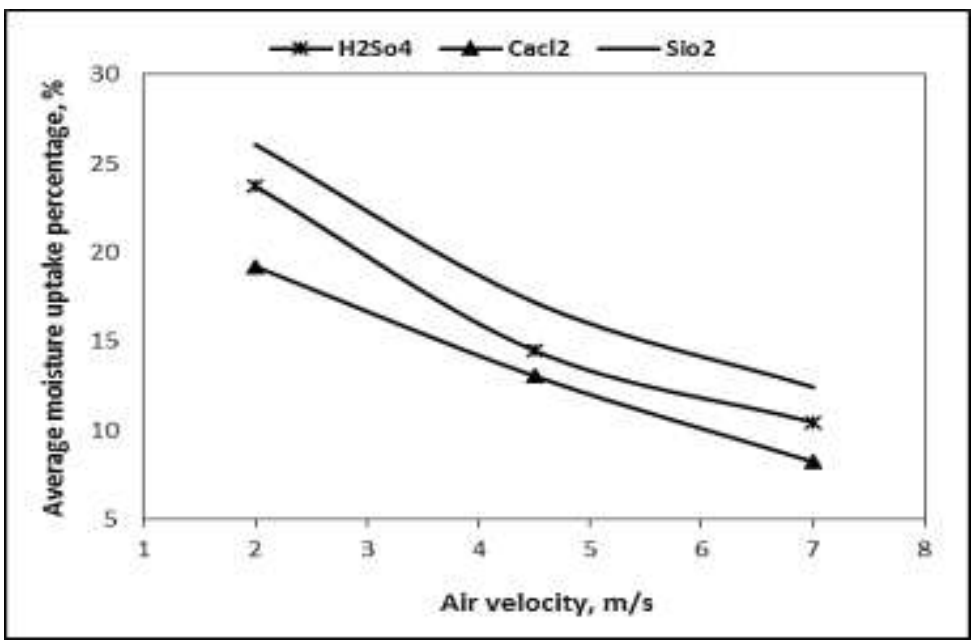

Fig.3.1. the average of moisture uptake ratio by the desiccants at the air velocities (2- 4.5- 7) $\mathrm{m} / \mathrm{s}$.

\subsection{The average of moisture uptake using four configurations of desiccants:}

The data illustrated that the increase in the air velocity from 2 to $7 \mathrm{~m} / \mathrm{s}$ decrease the ability for moisture uptake by $63.21 \%, 59.3 \%, 61.46$ and $54.2 \%$ for the configurations conf.3, conf.4, conf.2 and conf.1 respectively as shown in fig. 3.2. So for garlic drying, conf.3 with air velocity $2 \mathrm{~m} / \mathrm{s}$ was selected as the promising DDS to be used. 


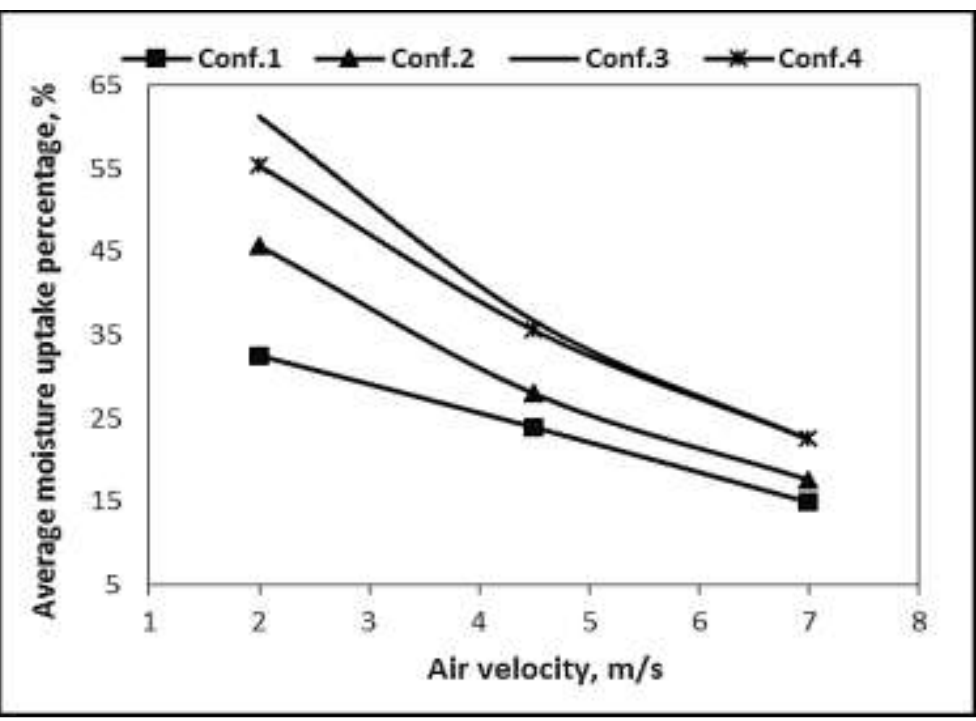

Fig.3.2. The average of the moisture uptake ratio by the four different configurations of desiccants at air velocities $(2-4.5-7) \mathrm{m} / \mathrm{s}$.

3.3. Effect of the drying methods on the garlic moisture content:-

Results illustrate that the moisture content decreases continually with drying time. A faster decrease in the moisture content of sliced garlic dried by DDS and oven, was noticeable during the early period of drying when the moisture content of the sample was still high. So a larger amount of moisture was removed from the sample easier at the beginning of the process. Moreover, the decrease in the moisture content of the sliced garlic was faster at the lower loading level $\left(1.15 \mathrm{~kg} / \mathrm{m}^{2}\right)$ due to the fact that the relative humidity $(\mathrm{RH})$ of drying air used at the three loading levels was not very different. So the absorption capacity of air used at the loading levels is quite similar. The initial moisture content of garlic was $182 \%$ on dry basis. The final moisture contents using DDS method were 7.56, 9.9 and $12.85 \%$ at the loading levels $1.15,2.3,4.6 \mathrm{~kg} / \mathrm{m}^{2}$ respectively, as shown in fig. 3.3. The final moisture contents using oven dryer were 5.62, 6.34 and $7.09 \%$ at the loading levels $1.15,2.3,4.6 \mathrm{~kg} / \mathrm{m}^{2}$ respectively, as shown in fig. 3.4.

\subsection{Effect of the drying methods on the garlic drying rate:-}

The curves illustrates that the drying rate increases as a result of increasing the moisture content. The loading level had much more effect on the drying rate of garlic slices. 


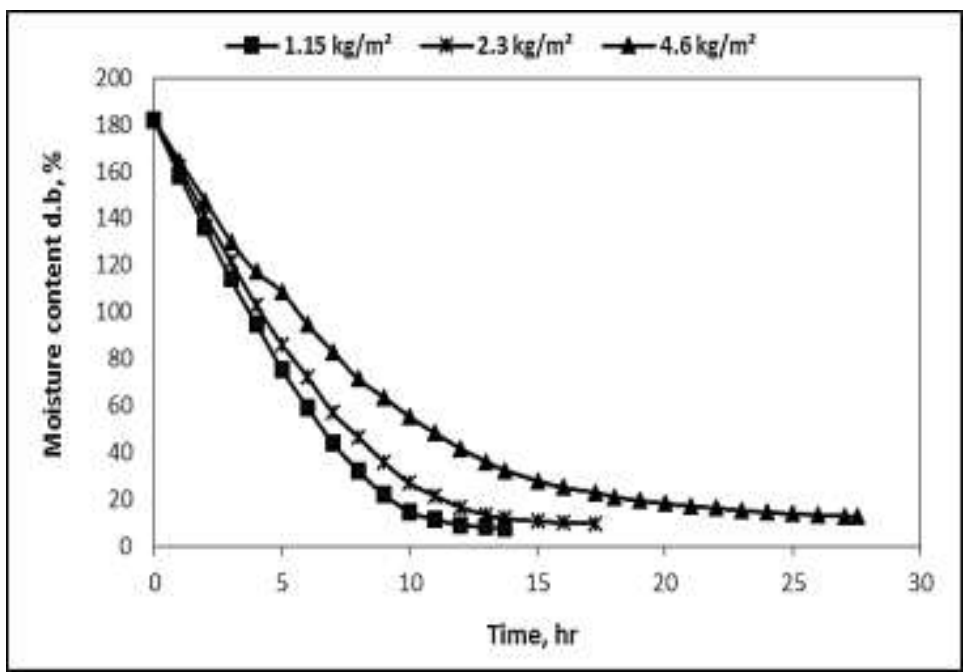

Fig. 3.3. Effect of desiccant drying method on the garlic moisture content at the three loading levels.

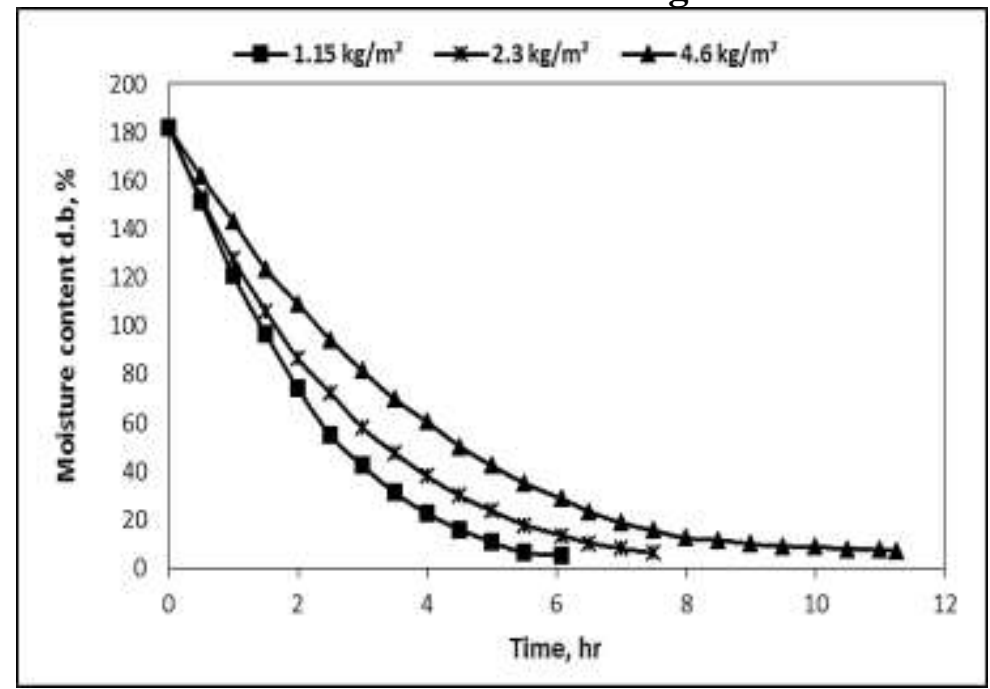

Fig. 3.4. Effect of the oven dryer on the garlic moisture content at the three loading levels.

The drying rate decreased with the increase in loading level and most of the drying process occurred in the falling rate period. It is clear that at high moisture content, the difference between drying rates at different loading levels was high, but at low moisture content, this difference was negligible. The average of the drying rates for DDS method were 0.125 , 0.107 and $0.078 \mathrm{gw} . / \mathrm{gd}$. hr. for the three loading levels 1.15, 2.3 and 4.6 $\mathrm{kg} / \mathrm{m}^{2}$ respectively, as shown in fig. 3.5. The average of the drying rates 
for oven were $0.294,0.234$ and $0.152 \mathrm{gw} . / \mathrm{gd}$. $\mathrm{hr}$. for three loading levels $1.15,2.3$ and $4.6 \mathrm{~kg} / \mathrm{m}^{2}$ respectively, as shown in fig. 3.6.

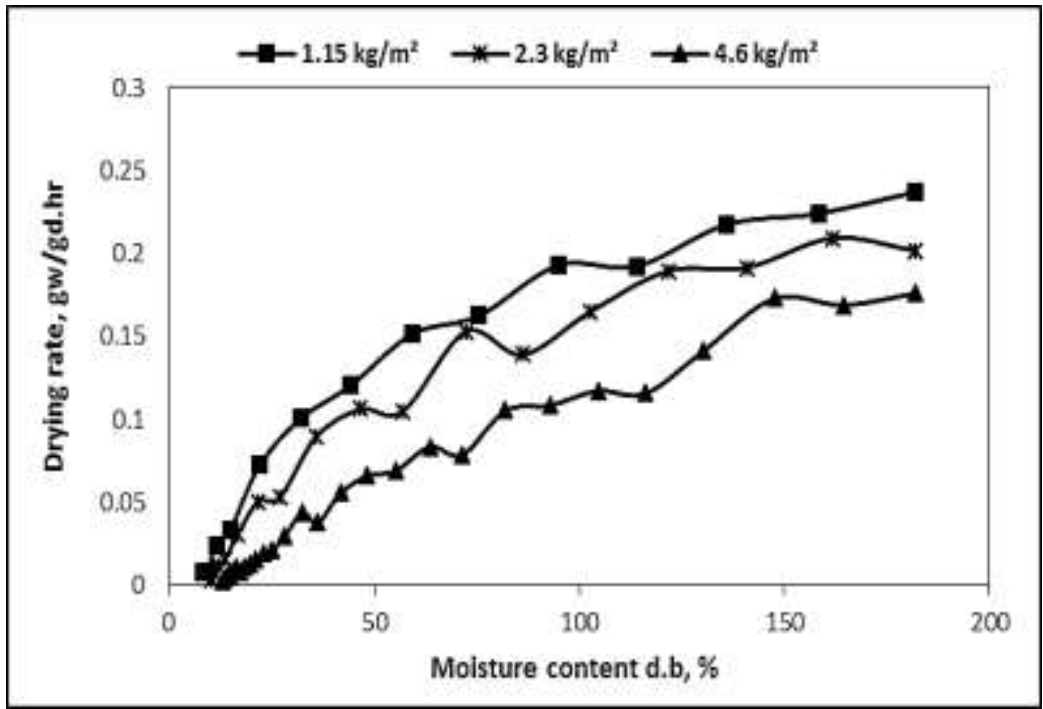

Fig. 3.5. Effect of the desiccant drying method on the garlic drying rate at the three loading levels.

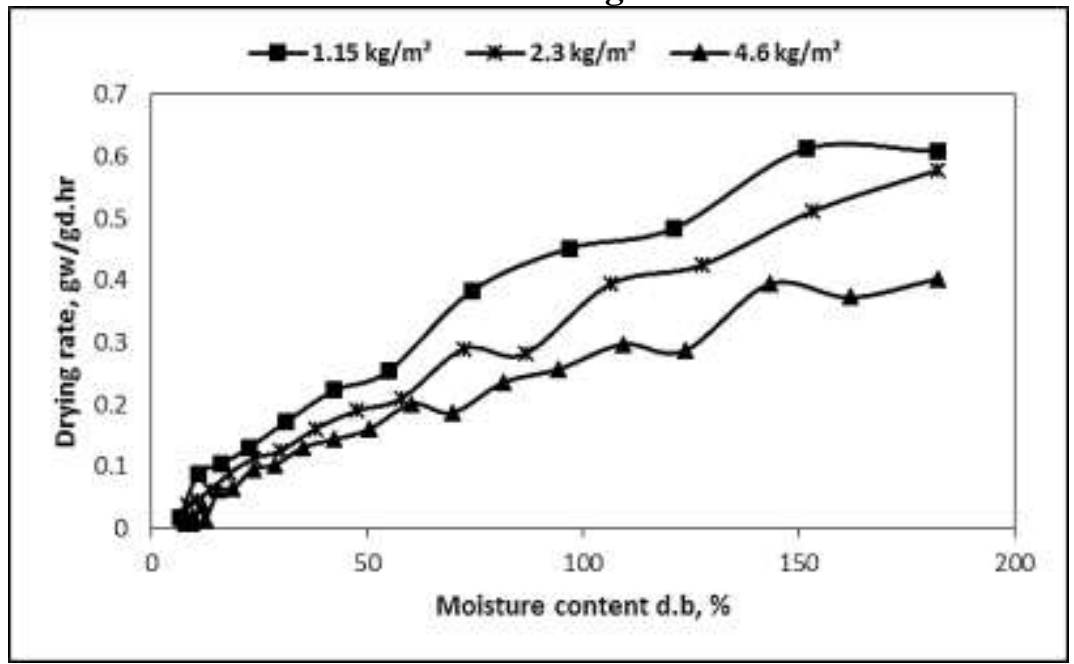

Fig. 3.6. Effect of the oven on the garlic drying rate at three loading levels.

\subsection{Effect of the drying methods on the energy consumption:-}

It's obvious that the specific energy consumption decreased as a result of increasing the loading level as shown in fig. 3.7 and fig. 3.8. For each loading level the specific energy consumption was nearly the same for the both of drying method. 


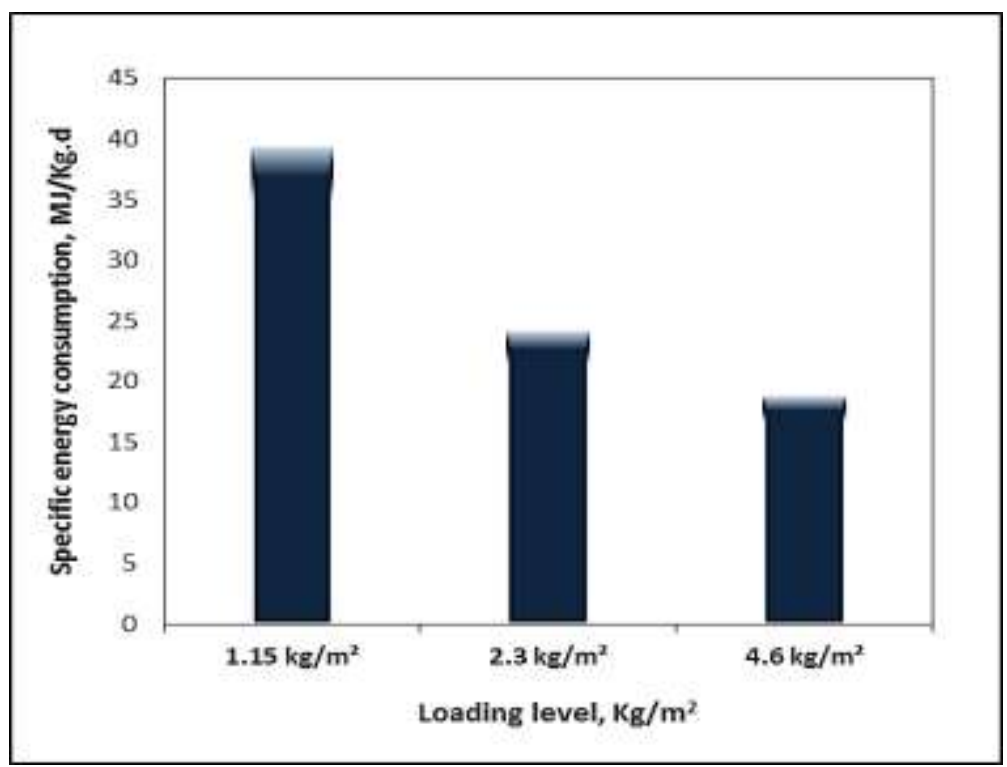

Fig. 3.7. Effect of the desiccant drying method on the specific energy consumption

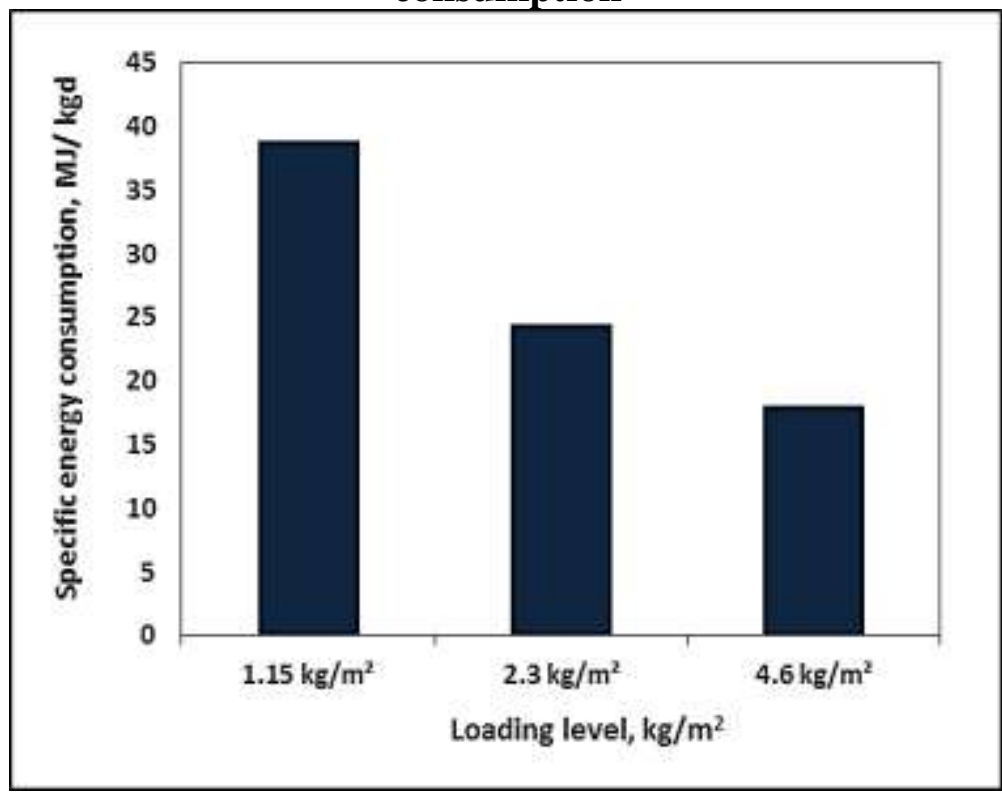

Fig. 3.8. Effect of the oven dryer on the specific energy consumption

\subsection{Effect of the drying methods on the drying efficiency:-}

The drying efficiency was always relative high at the beginning of the drying process due to increase in drying rate, through the Figure 3.9 and 3.10 it's clear that efficiency increased with increasing the loading levels. 


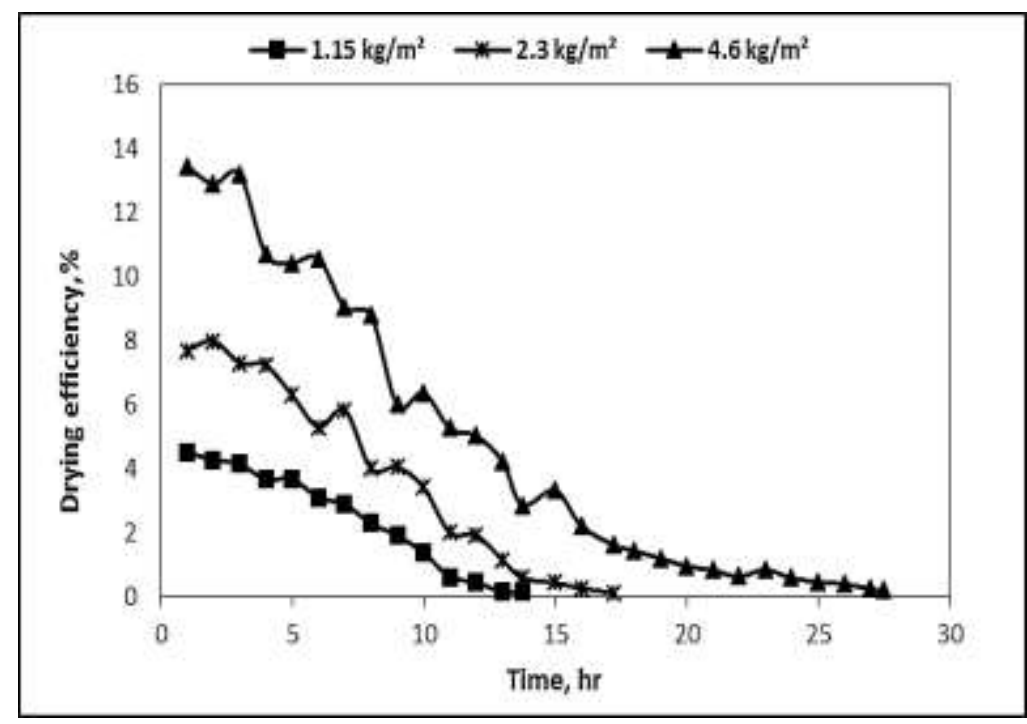

Fig. 3.9. Effect of the desiccant drying method on the drying efficiency

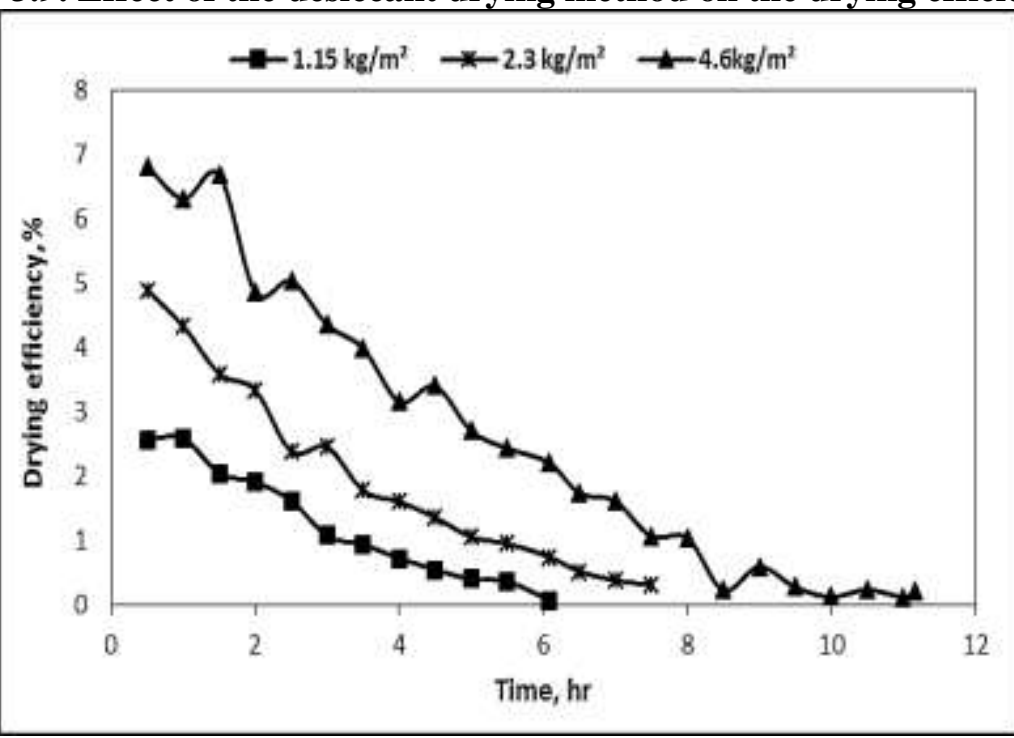

Fig. 3.10. Effect of the oven dryer on the drying efficiency

\subsection{Effect of the drying methods on the garlic oil content:-}

The oil content of garlic slices remarkably affected by the loading levels. Whenever the loading level increased the oil content decreased. The smallest loss in oils occurred during DDS drying method compared to the oven dryer as shown in fig. 3.11 and 3.12 This might be due to the high temperature $\left(70^{\circ} \mathrm{C}\right)$ used with oven drying subscribed in evaporating most of the oil content. 


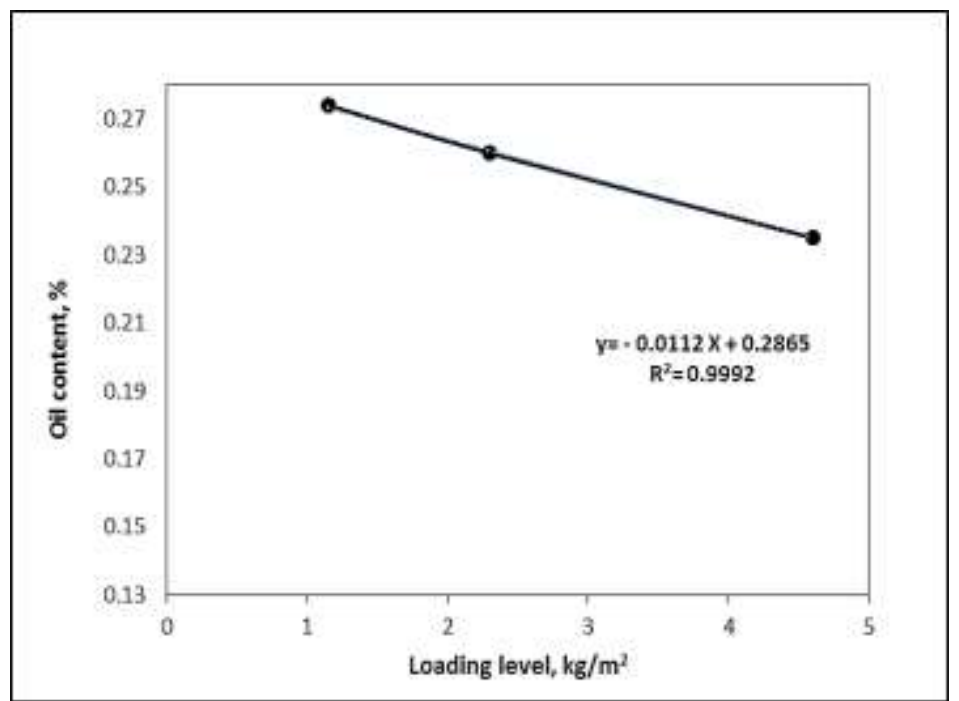

Fig. 3.11. The effect of desiccant drying method on the garlic slices oil

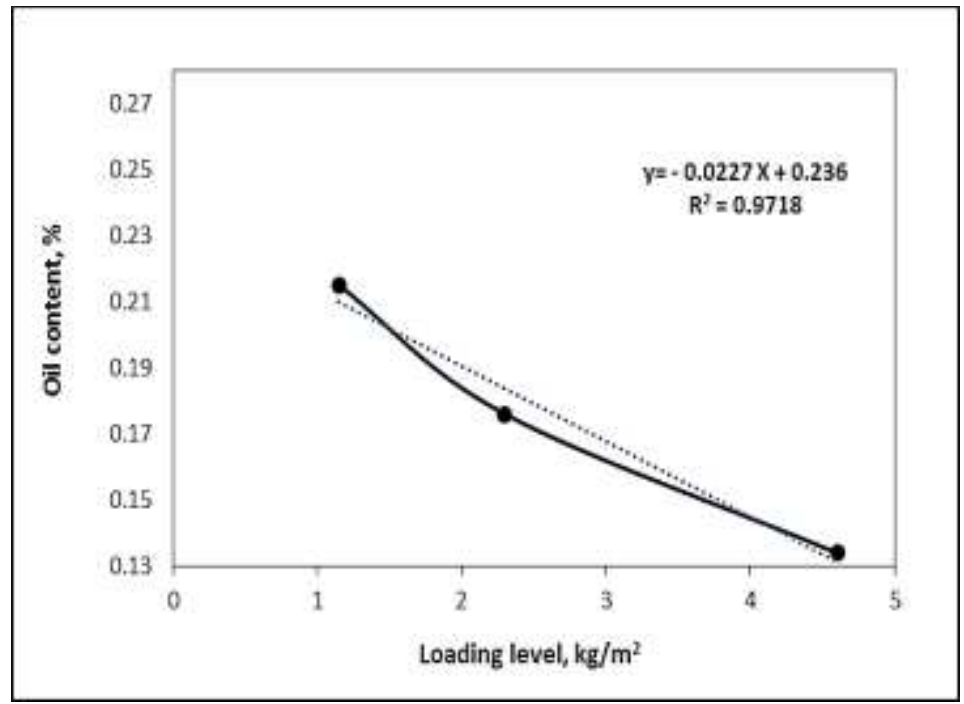

Fig. 3.12. The effect of oven drying on the garlic slices oil

\subsection{Effect of the drying methods on the garlic color properties:-}

From the results in fig 3.13 and 3.14 it was shown that the redness of garlic slices dried by both the used drying methods (DDS and oven dryer) compared with the fresh one increased significantly. This shows that all dried samples were significantly redder than the fresh ones. But indeed the color degradation was higher in the oven dryer method, this might be owing to the high temperature. 


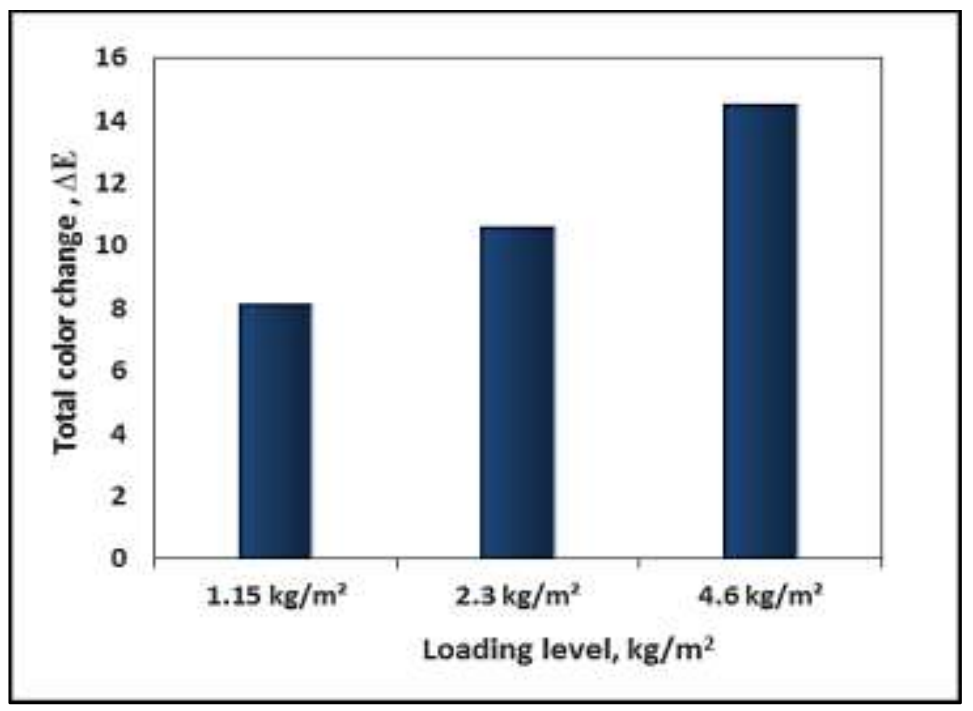

Fig. 3.13. The effect of the desiccant drying system on the garlic slices color change.

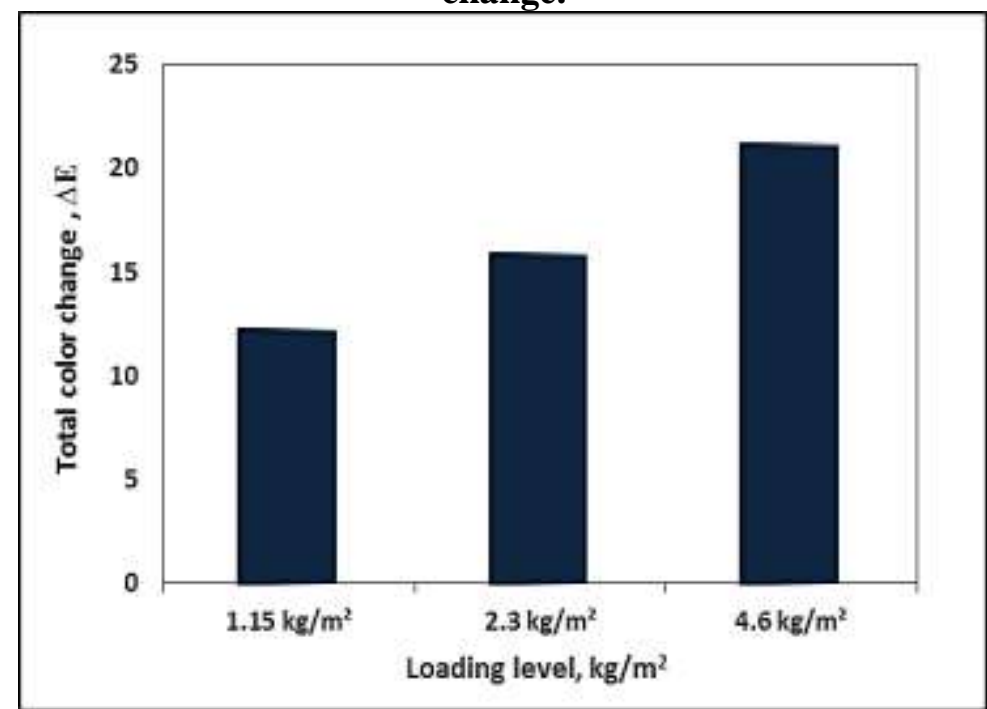

Fig. 3.14. The effect of oven dryer on the garlic slices color change.

\section{CONCLUSIONS}

1) The DDS had a high ability for moisture absorption from air. The best treatment was by using four desiccants of $500 \mathrm{ml} \mathrm{H}_{2} \mathrm{SO}_{4}, 500 \mathrm{gm}$ $\mathrm{CaCl}_{2}, 500 \mathrm{ml} \mathrm{H}_{2} \mathrm{SO}_{4}$ and $500 \mathrm{gm} \mathrm{SiO}_{2}$ at the lowest air velocity $(2.0$ $\mathrm{m} / \mathrm{s}$ ) by a moisture uptake percent of $61.27 \%$.

2) The DDS method considered as a suitable method for drying garlic slices because it realizes the objective of the study, as the DDS 
method maintained higher percent of oil content in the dried garlic slices compared to the oven dryer.

3) The DDS method maintained the original color of raw garlic samples, the color change $\Delta \mathrm{E}$ was $8.175 \%$ at the lowest loading level 1.15 $\mathrm{kg} / \mathrm{m}^{2}$, and was $12.24 \%$ by using oven dryer At the same loading level.

\section{REFERENCES}

AOAC (1995). Official method of analysis, association of official analytical chemists. Washington, D.C. USA.

Aktas M., A. Khanlari, B. Aktekeli and A. Amini (2017). Analysis of a new drying chamber for heat pump mint leaves dryer. International Journal of Hydrogen Energy, 3: (7), 1-11.

Belessiotis V. and E. Delyannis (2011). Solar drying. Solar Energy, 85: $1665-1691$.

Gandhidasan P. (2004). A simplified model for air dehumidification with liquid desiccant. Solar Energy, 76: 409-416.

Huang H., T. Oike, F. Watanabe, Y. Osaka, N. Kobayashi and M. Hasatani (2010). Development research on composite adsorbents applied in adsorption heat pump. Applied Thermal Engineering, 30:1193-1198.

Kamil S. and Ahmet K. (2006). The thin layer drying characteristics of organic apple slices. Journal of Food Engineering (73): 281-289.

Papu S., A. Singh, S. Jaivir, S. Sweta, A. M. Arya and B. R. Singh (2014). Effect of Drying Characteristics of Garlic-A Review. Food Processing \& Technology, 5: (4), 1-318.

Rasouli M., S. Seiiedlou, H. R. Ghasemzadeh and H. Nalbandi (2011). Convective drying of garlic (Allium sativum L.): Part I: Drying kinetics, mathematical modeling and change in color. Australian journal of crop science, 5: (13), 1707-1714.

Rihan Y. A. and B. Abd El-Bary (2009). Characteristics of desiccant polymers for air conditioning systems. Journal of radiation research and applied sciences, 2: (3), 449-465. 
Sharma G.P. and S. Prasad (2001). Drying of garlic (Allium sativum) cloves by microwave-hot air combination. Journal of Food Engineering, 50: 99-105.

Singh K., S. Singh, P. Singh and R.S. Gill (2017). Dehumidification using desiccants along with vapor compression system. Mechanica Confab, 6: (1), 2320-2491.

\section{الملخص العربى - المب \\ استخدام هواء منزوع الرطوبة فى تجفيف شرائح الثوم

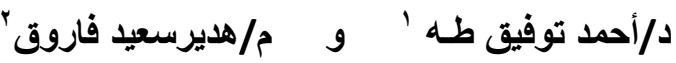

أجرى هذا البحث بمعمل الهندسة الزراعية كلية الزراعة جامعة المنوفية بهدف بحث طريقة

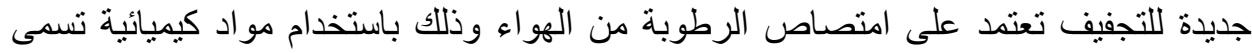

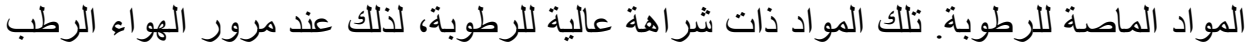

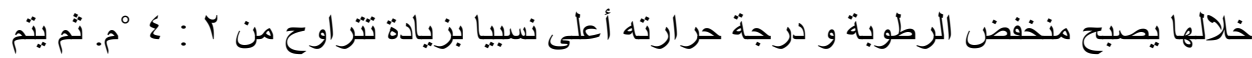

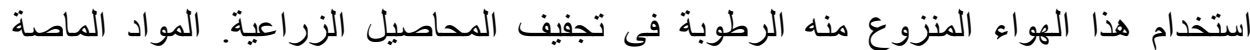

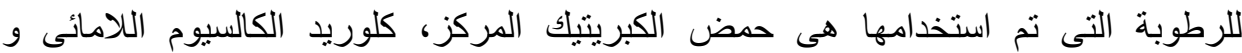

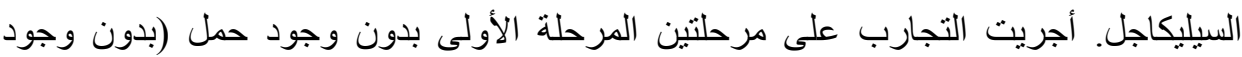

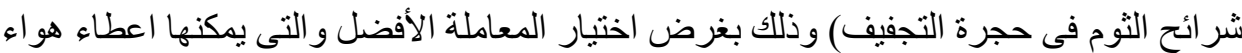

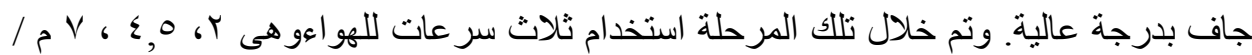

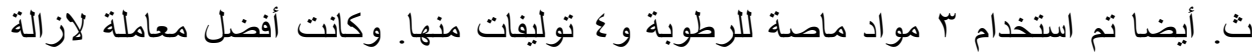

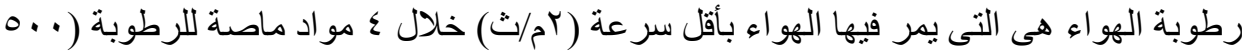

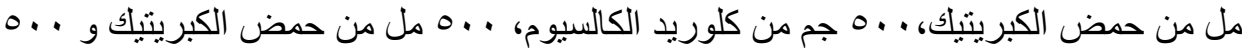

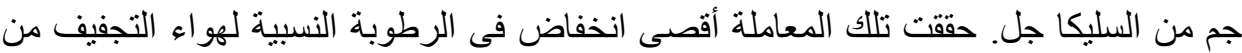

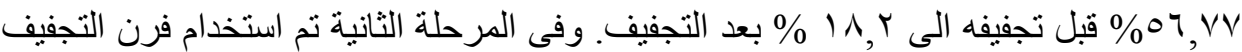

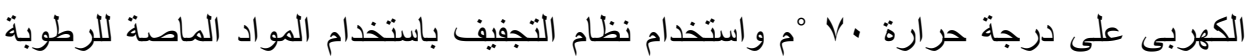

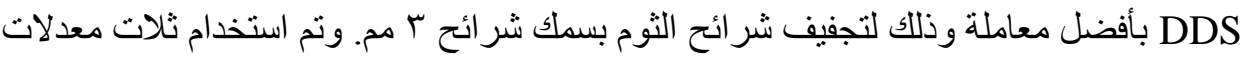

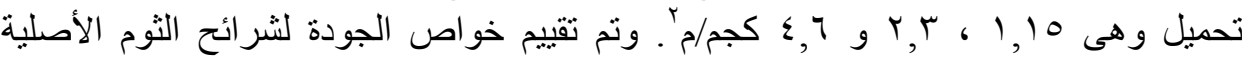
و المجفقة على أساس اللون ومحتوى الزيت. وأوضحت النتائج أن استخدام طريقة التجفيف

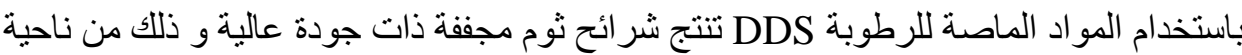

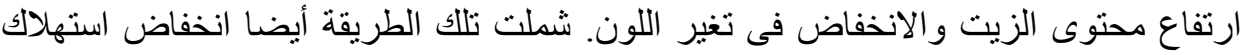
الطاقة وارتفاع كفاءة التجفيف مقارنة باستخدام فرن التجفيف.وتوصلت الدارئ التفة الي النتائج 


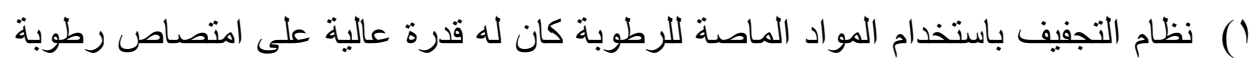

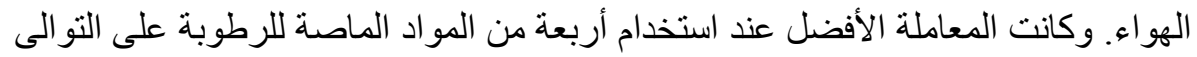
و هى . .0 مل من وان

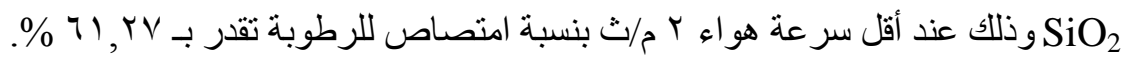

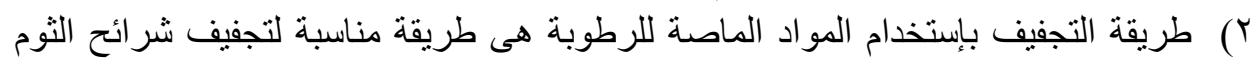

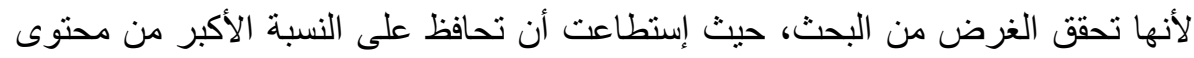

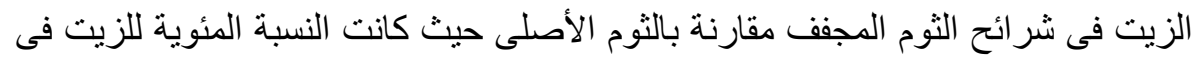

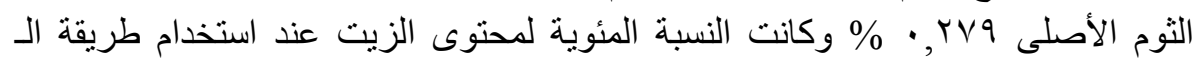

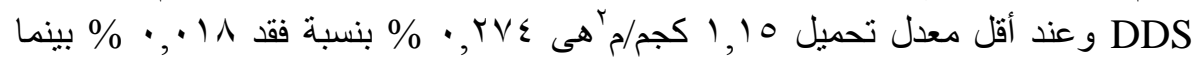

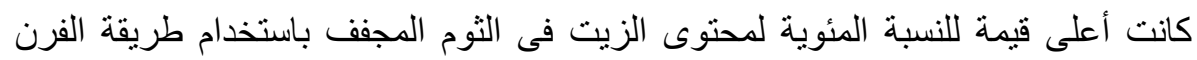

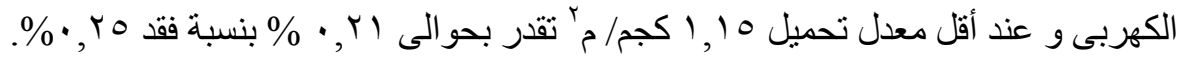

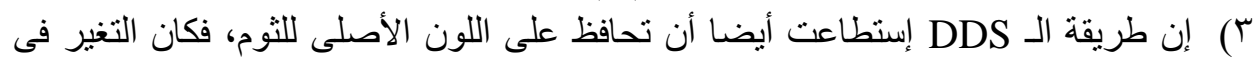

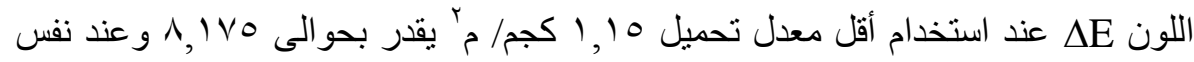
معدل التحميل كان التغير فى اللون DE باستخدام طريقة الفرن الكهربى يقدر بحوالى الى الى . Ir, r

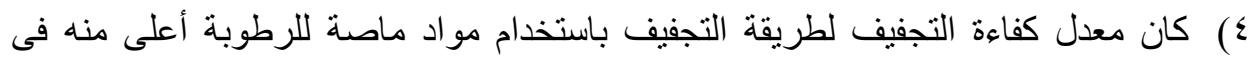

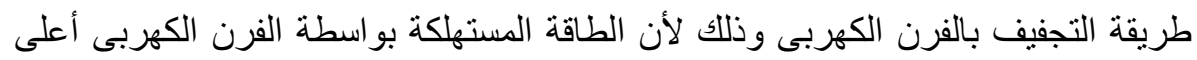
من المستهلكة بو اسطة طريقة الـ DDS. 